\title{
China and the WTO Dispute Settlement System: From Passive Observer to Active Participant?
}

\author{
Kristie THOMAS* \\ $\underline{\text { Abstract }}$ \\ Since China's accession to the World Trade Organisation (WTO) in \\ December 2001, it has participated in a relatively small number of cases \\ brought to the WTO Dispute Settlement Body (DSB), contrary to the many \\ wild predictions made prior to entry. In the first few years post-accession, \\ China seemed content to act as a passive observer, participating mainly as \\ a third party. However, since 2006, there appears to have been a shift in \\ attitude with China now taking a more combative stance, particularly in the \\ past few years. This article will examine China's participation in the WTO \\ DSB from 2002 to date to explore whether China's approach really has \\ shifted from that of passive observer to that of an active participant, \\ possible reasons to explain this transformation and what the implications of \\ such a shift may be for other WTO Contracting Parties.
}

$\underline{\text { Keywords }}$

WTO, dispute settlement, international trade disputes, China

\section{Introduction}

It is clear that dispute settlement is viewed as one of the central pillars of the WTO multilateral trading system and the WTO itself claims it is "the WTO's unique contribution to the stability of the global economy," and that it "makes the trading system more secure and predictable." ${ }^{\prime}$ However, prior to China's WTO accession in December 2001, concerns were raised that China's membership could bring a flood of bilateral trade disputes to the DSB and dispute settlement was thus seen as an area of key importance in China's accession negotiations.

Why was China's participation in the WTO dispute settlement system judged to be so crucial? Firstly, it is clear that "the WTO's dispute settlement mechanism is widely regarded as the jewel in the crown of the Uruguay Round and the very heart of the WTO." ${ }^{2}$ As a result, the efficient functioning of the dispute settlement system, including the willing

\footnotetext{
* Lecturer in Business Law, Nottingham University Business School, University of Nottingham, email: kristie.thomas@nottingham.ac.uk

${ }^{1}$ World Trade Organisation, "Understanding the WTO: Settling Disputes- A Unique Contribution" http://www.wto.org/english/thewto_e/whatis_e/tif_e/disp1_e.htm. Accessed February 4th 2010.

${ }^{2}$ Bernhard Speyer, "Dispute Settlement: A Gem in Need of Polish and Preservation," in The World Trade Organization Millenium Round: Freer Trade in the Twenty-First Century, ed. Klaus Günter Deutsch and Bernhard Speyer (London: Routledge, 2001), 275.
} 
participation of key WTO Members, is essential for the future of the world trading system. In addition, there are continued concerns about the low levels of participation by developing countries in the dispute settlement system. It is obvious that, "the system will survive and flourish only if all (or at least a vast majority) of its Members feel that they have the ability to adequately protect their WTO rights." ${ }^{3}$ China, as one of the largest developing country Members in the WTO, can offer important lessons and guidance for other developing countries seeking to increase their participation in dispute settlement. Finally, China's participation in the WTO dispute settlement system can act as "an important source from which to track China's transition to full WTO membership."4

China formally entered the WTO on December 11th 2001 and from that date is subject to all the agreements that make up the WTO including the Dispute Settlement Understanding (DSU). Since China's WTO accession in 2001, its interactions with the world trading system have shown a marked shift from an initial focus on amending domestic legislation in order to comply with WTO rules and disciplines, to a more assertive stance. It is this shift and the associated implications for China's trading partners which is the focus of this article.

This article will be organised into four sections: firstly, the predictions which were made prior to China's accession in 2001 will be examined; then, China's actual pattern of interaction with the WTO DSB from 2002-2011 will be outlined to see if these predictions materialised. Thirdly, the pattern which emerges from these disputes will be considered and explained in more detail. The final section will then consider how this pattern of interaction may affect China's future interactions with the DSB and the consequences for other WTO Contracting Parties.

\footnotetext{
${ }^{3}$ Christopher C. Parlin, "Operation of Consultations, Deterrence, and Mediation," Law and Policy in International Business 31, no. 3 (2000): 572.

${ }^{4}$ Chad P. Bown, "China's WTO Entry- Antidumping Safeguards and Dispute Settlement," NBER Working Paper No. 13349 (2007): 32.
} 


\section{Predictions of China's Impact on the WTO Dispute Settlement System}

Prior to WTO accession, there was a chorus of warnings of a flood of China-related complaints being brought to the DSB immediately upon entry. ${ }^{5}$ It was even feared that this torrent of complaints could "overwhelm the already overburdened system" DSB to a standstill. There were a number of factors that led observers to fear a deluge of formal WTO complaints against China. It was clear that it would not be easy for China to fully comply with its WTO obligations immediately upon accession, not only because the expectations of the international community were so high, but also because China had agreed to various onerous 'WTO-plus' commitments surpassing the minimum commitments required. $^{7}$ For example, China agreed to a transitional safeguard clause in the Protocol of Accession which makes it much easier for other Members to impose restrictions on imports from China, as proof of only 'market disruption' is required rather than serious injury. ${ }^{8}$

Secondly, there were several economic factors that were held to correlate positively with increased interaction in the dispute settlement system, namely: "China's size, its trade surplus with the USA and the EU and the dual nature of its economy." " Logically, previously studies have found that the number of actual disputes a Member country is involved in is directly related to the amount of trade a country undertakes. ${ }^{10}$ As China's share of current world trade is significant to say the least, it is a logical consequence that China would also feature in a large number of WTO disputes.

China's share of global trade has expanded significantly since the start of the reform and opening-up period in 1978, beginning "relatively slowly in the 1980s after the relaxation of pervasive and complex import and export controls, but accelerat[ing] in the 1990s with

\footnotetext{
${ }^{5}$ Rahul Jacob, "No Quick Way to Sort out Differences: WTO Accession: Dispute Resolution," Financial Times, November 13th 2000.

${ }^{6}$ See for example, Sylvia Ostry, "WTO Membership for China: To Be and Not to Be: Is That the Answer?," in China and the World Trading System: Entering the New Millenium, ed. Deborah Z. Cass, Brett G. Williams, and George Barker (Cambridge: Cambridge University Press, 2004), 37.

${ }^{7}$ Chulsu Kim, "East Asia in the WTO Dispute Settlement Mechanism," in The WTO in the Twenty-First Century: Dispute Settlement, Negotiations and Regionalism in Asia, ed. Yasuhei Taniguchi, Alan Yanovich, and Jan Bohanes (Cambridge: Cambridge University Press, 2007), 265.

${ }^{8}$ Nicholas R. Lardy, Integrating China into the Global Economy (Washington: Brookings Institution Press, 2001), 154.

${ }^{9}$ Speyer, "Dispute Settlement: A Gem in Need of Polish and Preservation," 283.

${ }^{10}$ Henrik Horn, Petros C. Mavroidis and Håkan Nordström, "Is the Use of the WTO Dispute Settlement System Biased?" (1999) in The WTO and International Trade Law, ed. Petros C. Mavriodis and Alan O. Sykes (Cheltenham: Edward Elgar Publishing, 2005).
} 
broader trade reforms, including significant tariff reductions." ${ }^{11}$ Indeed, as China's share of global trade began to grow in the 1990s, bilateral tensions with trading partners such as the US escalated. For example, in the 1990s, the US grew increasingly impatient at the slow pace of reforms in the field of intellectual property (IP) protection and consequently threatened massive sanctions under Section 301 of the US Trade Act 1974 in 1991, 1994 and 1996. ${ }^{12}$ On each occasion, an Agreement or Memorandum of Understanding (MOU) in which China promised further improvements in the IP system was reached at the last minute, but this destructive cycle of threatened unilateral sanctions and forced concessions was heavily criticised. ${ }^{13}$ Not only did it lose credibility for the US, but it also stirred up resentment among the Chinese. Therefore, the WTO dispute settlement mechanism was seen as a more credible and sustained alternative to resolve the existing trade tensions.

Additionally, there were thought to be geo-political factors which made the initiation of formal complaints against China more likely. Specifically, "foreign governments wary that the trade giant is stealing market share" ${ }^{, 14}$ may be susceptible to domestic pressure to pursue China to the WTO dispute settlement body. A further political factor hotly debated prior to WTO accession was the virtually simultaneous entry of Taiwan to the WTO as a separate customs territory. As the first major international organisation of which both China and Taiwan were full members, the WTO provides a platform for cross-straits differences to be debated at an international level. It was feared that, "as Beijing and Taipei appear to be constantly obsessed with political concerns that override trade considerations, both parties are likely to politicize the use of the dispute settlement mechanism at the cost of effectiveness as well as the credibility of the procedures."15

However, despite widespread concerns about the impact of China's accession on the WTO's dispute settlement mechanism, the predicted flood of formal complaints failed to materialise. The next section will briefly give an overview of China's participation in the

\footnotetext{
${ }^{11}$ Thomas Rumbaugh and Nicolas Blancher, "China: International Trade and WTO Accession," (IMF Working Paper, 2004), 3.

${ }^{12}$ G. S. Feder, "Enforcement of Intellectual Property Rights in China: You Can Lead a Horse to Water but You Can't Make It Drink," Virginia Journal of International Law 37, no. 1 (1997): 240.

${ }^{13}$ For an overview of Sino-US relations with regards to IP during this period see: S. La Croix and D. E. Konan, "Intellectual Property Rights in China: The Changing Political Economy of Chinese-American Interests," World Economy 25, no. 6 (2002)..

${ }^{14}$ Peter Wonacott, "As WTO Entry Looms, China Rushes to Adjust Legal System," Wall Street Journal, November 9th 2001.

${ }^{15}$ Qingjiang Kong, "Can the WTO Dispute Settlement Mechanism Resolve Trade Disputes between China and Taiwan?," Journal of International Economic Law 5, no. 3 (2002): 747.
} 
dispute settlement system from 2002 to date, both as a complainant, as a respondent and also as a third party. 


\section{China's Participation in Dispute Settlement 2002- $2011^{16}$}

Given China's share of world trade, it might be expected that China's involvement in the DSB would be comparable to the US or the EU. However, it is clear from Table 1 below, illustrating how China's involvement with the WTO DSB compares to other selected WTO Members, that China's formal involvement in disputes, particularly as a complainant, is far less than may have been expected from the predictions made in the preceding section. China's changing participation in these disputes from accession to date will be considered in more detail below.

Table 1: Selected WTO Members' Involvement in the DSB, 2002-2011

\begin{tabular}{|l|c|c|c|c|}
\hline WTO Member & $\frac{\text { As complainant }}{(1995-\text { to date })}$ & $\frac{\text { As respondent }}{(1995-\text { to date })}$ & $\frac{\text { As complainant }}{\frac{(\mathbf{2 0 0 2 - 2 0 1 1})}{2}}$ & $\frac{\text { As respondent }}{\frac{(\mathbf{2 0 0 2 - 2 0 1 1})}{21}}$ \\
\hline China & $/$ & $/$ & $\mathbf{8}$ & $\mathbf{2 1}$ \\
\hline Chinese Taipei & $/$ & $/$ & $\mathbf{3}$ & $\mathbf{2}$ \\
\hline Brazil & 25 & 14 & $\mathbf{6}$ & $\mathbf{7}$ \\
\hline India & 19 & 20 & $\mathbf{9}$ & $\mathbf{3}$ \\
\hline Korea & 15 & 14 & $\mathbf{5}$ & $\mathbf{3}$ \\
\hline Japan & 14 & 15 & $\mathbf{1 1}$ & $\mathbf{7}$ \\
\hline Mexico & 21 & 14 & $\mathbf{2 8}$ & $\mathbf{5 7}$ \\
\hline US & 97 & 113 & $\mathbf{2 7}$ & $\mathbf{3 7}$ \\
\hline EU & 83 & 70 & & \\
\hline
\end{tabular}

\subsection{Cautious Beginnings, 2002-2005}

Contrary to the wild predictions made prior to China's WTO entry outlined in the previous section, China's initial interactions with the DSB were somewhat limited. China's first dispute brought as a complainant was in 2002; however, this case (DS252- regarding safeguard measures that the US had imposed on steel imports) had eight co-complainants and China did not really take a leading role in the dispute. The result of the dispute was never really in doubt as the worldwide media had been fairly united in condemning the US and furthermore, every safeguard measure which had been challenged up until that point had been

\footnotetext{
${ }^{16}$ All figures given for WTO disputes are correct as of June $1^{\text {st }} 2011$.
} 
declared inconsistent with WTO principles. ${ }^{17}$ Therefore, China could safely 'piggy-back' on the strong team of co-complainants and the outcome "was arguably a by-product of the legal efforts undertaken by more active WTO members in the case such as the EU."18

Subsequently, China's first real experience with the DSB came in 2004 when China was the respondent in a dispute brought by the US over VAT imposed on integrated circuits. China continued to show a cautious attitude in this case, possibly because it still "viewed the initiation of legal disputes as synonymous to the break-up of diplomatic relations with the other countries." 19 As a result, China was quick to settle this dispute through negotiations and a mutually agreed solution was notified to the WTO in October 2005. In addition, other trade disputes which arose during this period were also resolved through bilateral negotiations instead of through the formal dispute settlement process provided by the WTO. For example, the EC threatened to bring a WTO case against China in 2004 over its export restrictions on coke; China soon capitulated and restored the existing export levels rather than defend the restrictions at the WTO. ${ }^{20}$ China also backed down in late 2005 when the US threatened to bring a formal WTO case over its antidumping determination regarding linerboard. ${ }^{21}$

However, in stark contrast to China's reluctance to get involved with formal WTO disputes as a complainant or respondent immediately after acceding to the WTO, China proved keen to get involved with many disputes as a third party. As can be seen in Figure 1, China has been actively involved in a large number of WTO disputes as a third party from 2002 onwards. In particular, it joined a large proportion of the cases brought to the WTO in 2002-6 as a third party, whereas such involvement has dropped off somewhat in recent years, as China has become more formally involved in disputes both as a complainant and as a respondent.

\footnotetext{
${ }^{17}$ Henry Gao, "Aggressive Legalism: The East Asian Experience and Lessons for China," in China's Participation in the WTO, ed. Henry Gao and Donald Lewis (London: Cameron May, 2005), 325-6.

${ }^{18}$ Bown, "China's WTO Entry- Antidumping Safeguards and Dispute Settlement," 33.

${ }^{19}$ Henry Gao, "Taming the Dragon: China's Experience in the WTO Dispute Settlement System," Legal Issues of Economic Integration 34, no. 4 (2007): 376.

${ }^{20}$ Victoria Knight and Scott Miller, "EU May Battle China over Key Export Quota," Wall Street Journal, May 6th 2004.

${ }^{21}$ Julia Ya Qin, "Trade, Investment and Beyond: The Impact of WTO Accession on China's Legal System,"

China Quarterly 191(2007): 739.
} 
Figure 1- China's involvement in WTO disputes, 2002-2010

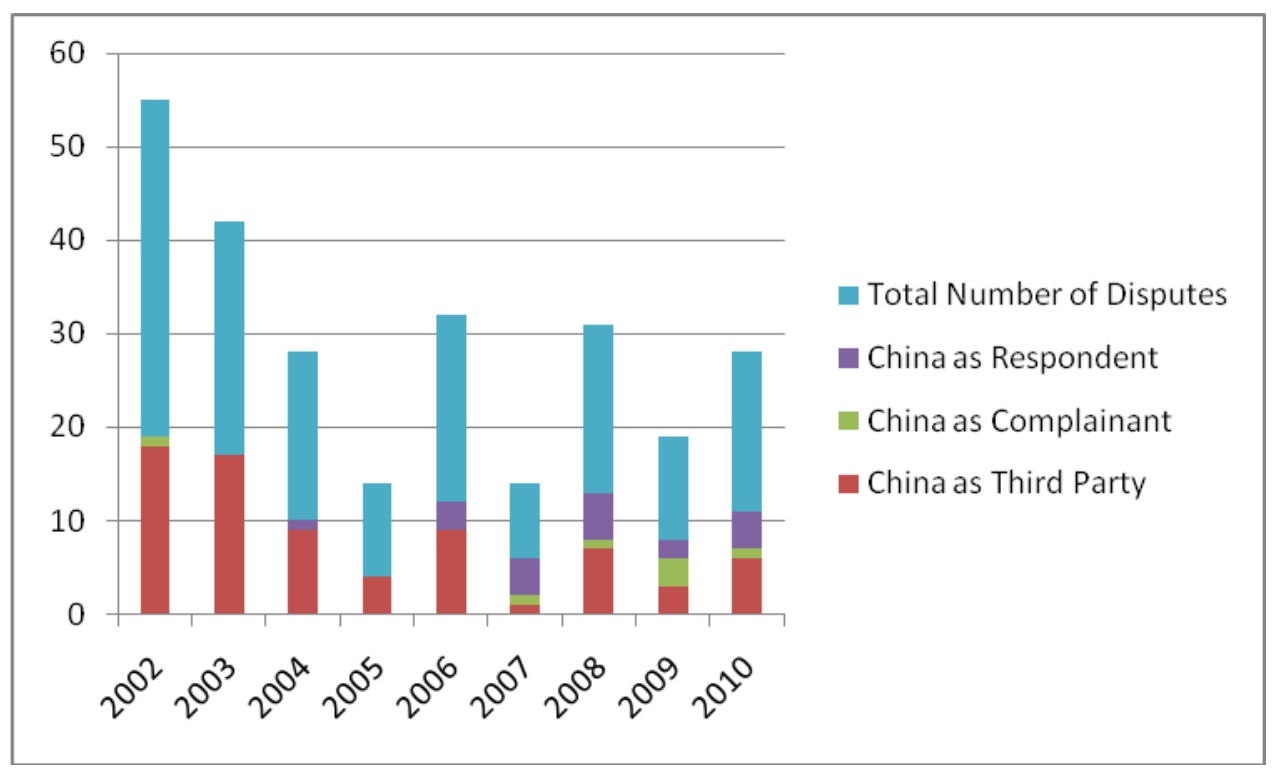

Furthermore, as can be seen from Table 2, not only has China participated in a large number of disputes as a third party, but it has also participated as a third party more frequently than almost any other WTO Member over the period 2002-2011.

Table 2: Selected WTO Members' Involvement as a Third Party, 2002-2011

\begin{tabular}{|l|c|}
\hline WTO Member & Involvement as Third Party \\
\hline China & $\frac{(\mathbf{2 0 0 2 - 2 0 1 1})}{74}$ \\
\hline Chinese Taipei & 56 \\
\hline Brazil & 48 \\
\hline India & 36 \\
\hline Korea & 39 \\
\hline Japan & 61 \\
\hline Mexico & 39 \\
\hline US & 43 \\
\hline EU & 63 \\
\hline
\end{tabular}

This enthusiasm for participating in disputes as a third party is in sharp contrast to China's initial reluctance to bring a formal dispute to the WTO on its own behalf; a reluctance which started to shift following the filing of a flurry of cases against China. 


\subsection{The Gloves Come Off, 2006-2007}

A shift in China's relationship with the WTO DSB appears to have begun in 2006 with the initiation of a formal complaint against China regarding certain measures affecting imports of automobile parts (DS339, DS340 and DS342). This complaint was brought by the relative WTO heavyweights of the EC, the US and Canada. In contrast to China's conciliatory stance during the trade disputes of 2004-5, China refused to concede during consultations and took the dispute to a full panel report. The panel held in July 2008 that China had discriminated against imported car parts and thus represented China's first legal defeat at the WTO. ${ }^{22}$ China appealed against certain elements of the panel's report, but the appellate body upheld the panel findings and China subsequently agreed to modify the disputed measures in order to comply with its obligations under the GATT 1994. However, it is significant that whilst the panel process was ongoing, China could benefit from keeping the disputed measures in place and this may be a consideration in future disputes as China as respondent decides whether to settle quickly or take the dispute to a formal panel report.

The auto-parts complaint was followed in February 2007 by a complaint brought by the US and Mexico over measures granting refunds, reductions or exemptions from taxes (DS358 and DS359). The complaint alleged that these measures acted as export subsidies or import substitution subsidies for the manufacturing sector prohibited under WTO rules. Following extensive consultations, an agreement was reached and notified to the WTO in December 2007. In this dispute, China appeared to be unhappy with the speed at which the establishment of a panel was requested, whilst consultations and legal amendments were still being undertaken.

Given the publicity surrounding China's poor intellectual property enforcement, ${ }^{23}$ it is perhaps surprising that China had not been the respondent in a case involving compliance with the Agreement on Trade-Related Aspects of Intellectual Property Rights (TRIPS) before 2007, but on $10^{\text {th }}$ April 2007, the US finally circulated two related requests for consultations with China. The first of these (DS362) concerned measures affecting trading rights and distribution services for certain publications and audiovisual entertainment products such as movies, DVDs, videos, publications or books. ${ }^{24}$ The second (DS363) concerned measures

\footnotetext{
${ }^{22}$ Frances Williams, "WTO Rules against China in Dispute over Car Part Import Tariffs," Financial Times, July 19 th 2008.

${ }^{23}$ In particular, from the United States Trade Representative (USTR) who have placed China on its Priority Watch List for poor intellectual property enforcement for 6 consecutive years.

${ }^{24}$ World Trade Organisation, "China- Measures Affecting Trading Rights and Distribution Services for Certain Publications and Audiovisual Entertainment Products," (2007) Document WT/DS363/1.
} 
affecting the protection and enforcement of intellectual property rights. ${ }^{25}$ China's reaction to the initiation of these WTO complaints was strenuous denial and disappointment that the US had deemed this action necessary. ${ }^{26}$

Overall, the focus of the United States' submission was on fairly minor procedural aspects of the intellectual property system in China. Several of the grounds for complaint may simply have arisen from imprecise language in the primary legislation, such as the doubt over whether prohibiting illegal reproduction and distribution includes illegal reproduction or distribution only. Consequently, this reflects the problem of bringing a complaint to the WTO DSB in general; as distinguishing compliance from non-compliance is a largely subjective process, a complainant requires evidence of systemic failures not just complaints about inadequate law enforcement. ${ }^{27}$ Nevertheless, the panel report for dispute DS362 largely supported the US and to date, China has made good progress towards implementing the report's recommendations for legislative amendments. ${ }^{28}$ In DS363, although the panel report was circulated in August 2009, China and the US both appealed certain findings and the Appellate report was completed in December 2009, which found that some specific measures were inconsistent with China's WTO obligations. China has now amended most of the disputed measures in line with the panel's recommendations.

Following these disputes being brought against China, China finally initiated a dispute on its own merits, rather than 'piggybacking' on an existing dispute as had been the case in the steel safeguards dispute of 2002. In September 2007, China requested consultations with the US regarding determinations of anti-dumping and duty for coated paper from China (DS368). The dispute raises important questions about China's status as a non-market economy and the calculation of anti-dumping and countervailing duties. ${ }^{29}$ However, this dispute was short-lived as the US' preliminary trade restriction was never formally

\footnotetext{
25 _ for Consultations by the United States," (2007) Document WT/DS362/1.

${ }^{26}$ IPR.gov.cn, "Shangwubu Dui Meijiu Zhishichanquan Wenti Suzhu WTO Biaoshi Yihan (the Ministry of Commerce Expresses Regret over the WTO Dispute over IPR Brought by the US),"

http://int.ipr.gov.cn/ipr/inter/info/Article.jsp?a_no=107297\&col_no=774\&dir=200708. Accessed 20 August 2007.

${ }^{27}$ Gerald Chan., China's Compliance in Global Affairs: Trade, Arms Control, Environmental Protection, Human Rights (Singapore: World Scientific Publishing, 2006), 66.

${ }^{28}$ World Trade Organisation, "Status Report Regarding Implementation of the DSB Recommendations and Rulings in the Dispute: China-Measures Affecting the Protection and Enforcement of Intellectual Property Rights," (2010). Document WT/DS362/14.

${ }_{29}^{29}$ Gary Clyde Hufbauer, "Three US-China Disputes," (Paper prepared for Peterson Institute of International Economics 2 May 2007) http://www.iie.com/publications/papers/paper.cfm?ResearchID=749. Accessed 1 December 2009.
} 
imposed. ${ }^{30}$ Nevertheless, it seems that China's taste for bringing disputes to the DSB was undiminished by this misfiring as will be seen in the next section.

\subsection{Fighting Fire With Fire, 2008-2011}

Since the start of 2008, China's involvement with the WTO DSB has escalated; with China facing seven disputes as a respondent ${ }^{31}$ and initiating six disputes as a complainant. This arguably shows the maturing of China's interactions with the DSB as China is more willing to utilise the multilateral legalistic mechanisms available, rather than seeking to avoid the dispute settlement process. Of these thirteen disputes, there also appears to be a clear distinction between the issues on which China is willing to concede during the consultation period and those which China is more determined to take to a full panel hearing. These latter issues predominantly concern anti-dumping measures and other restrictions on what China regards as key export industries.

\subsubsection{Disputes settled through consultations}

The first dispute in which China was involved in as a respondent in this period involved measures affecting financial information services and foreign financial information suppliers. The complainants were the EU (DS372), the US (DS373) and Canada (DS378), alleging that China was restricting market access to news services through the official Xinhua news agency, clearly an area of some political sensitivity in China. However, an agreement was swiftly reached in this dispute, with China agreeing to allow foreign financial information suppliers to set up commercial operations in China. ${ }^{32}$

The second of the disputes to be settled through consultations concerned grants, loans and other incentives and consisted of three separate requests for consultations by the US, Mexico and Guatemala received in December 2008/January 2009. ${ }^{33}$ This dispute related specifically to subsidies which China was allegedly providing to domestic enterprises under the China World Top Brand Programme and the China Famous Export Brand Programme

\footnotetext{
${ }^{30}$ Chad P. Bown, "U.S.-China Trade Conflicts and the Future of the WTO," Fletcher Forum of World Affairs 33, no. 1 (2009): 33.

${ }^{31}$ Although there have been a total of thirteen complaints made against China in this period, some of these relate to separate requests from different WTO Members regarding the same substantive disputes and have thus been grouped together.

${ }_{32}$ Mure Dickie and Kathrin Hille, "Beijing Opens to Financial News Providers," Financial Times, November 14th 2008.

${ }^{33}$ Disputes numbered DS387, DS388 and DS390 respectively.
} 
contingent upon meeting export performance criteria. Following extensive consultations, China agreed to end the disputed subsidies in December 2009. ${ }^{34}$

Finally, China faced a request for consultations brought by the US concerning its subsidies for enterprises manufacturing wind power equipment, which the US alleged to favour domestic over imported goods. ${ }^{35}$ The dispute was initiated in December 2010, but by June 2011, China had agreed to end the disputed subsidy program. ${ }^{36}$ The swift resolution of these three disputes within the consultation period may suggest that China recognised that they were in breach of their WTO obligations, or that the disputes did not concern key industries or exports which China considered worthwhile defending to a full panel hearing, in stark contrast to the following set of disputes.

\subsubsection{Disputes taken to panel proceedings}

Eight of the thirteen disputes involving China since 2008 have not been resolved through consultations and have been taken to panel proceedings. Four of these involve antidumping measures, an issue which is of paramount importance to China. China is consistently the most frequent target of EU anti-dumping investigations ${ }^{37}$ and is also unhappy with many of the anti-dumping determinations carried out by the US. In September 2008, China launched a dispute against the US (DS379) relating to anti-dumping and countervailing duties on certain products from China, including pipes, pneumatic tyres and woven sacks. Consultations proved fruitless and a panel was established in January 2009, with the panel report issued in October 2010 and the Appellate Report in March 2011 and subsequently adopted. A particular point of interest for China was the US determination that state-owned enterprises in China (SOEs) were classed as 'public bodies'. This dispute also strikes at the heart of US trade policy whereby, since March 2007, China can be treated as a non-market economy in anti-dumping determinations but as a market economy under countervailing duty law; ${ }^{38}$ this inconsistency was at the heart of China's WTO complaint.

In addition to this dispute with the US, China has also initiated two anti-dumping related disputes against the EU recently. Both of these concern anti-dumping measures

\footnotetext{
${ }^{34}$ United States Trade Representative, "United States Wins End to China's "Famous Brand" Subsidies after Challenge at WTO” (December 2009) http://www.ustr.gov/about-us/press-office/pressreleases/2009/december/united-states-wins-end-china\%E2\%80\%99s-\%E2\%80\%9Cfamousbrand\%E2\%80\%9D-sub. Accessed 24 January 2010.

${ }^{35}$ Dispute DS419.

${ }^{36}$ BBC News, "China ends wind power subsidies after US challenge" (8 June 2011) http://www.bbc.co.uk/news/mobile/business-13692255. Accessed 11 June 2011.

${ }^{37}$ Qingjiang Kong, "Trade Disputes between China and the EU," (East Asian Institute, 2008), 5.

${ }^{38}$ Bown, "U.S.-China Trade Conflicts and the Future of the WTO," 44.
} 
imposed on Chinese exports: iron and steel fasteners in the first instance (DS397) and footwear in the second (DS405). China is concerned that there may be procedural irregularities in the EU's determination of dumping and has also voiced concerns about its status as a non-market economy (NME) and the implications this has for anti-dumping determinations. ${ }^{39}$ China scored a partial victory in the panel report regarding the dumping of fasteners with the panel finding the EU's anti-dumping measures were inconsistent with it's WTO obligations. However, this dispute is currently being considered by the Appellate Body and panel proceedings are still in progress for the footwear dispute.

The fourth recent dispute involving anti-dumping measures was brought by the US against China and concerns measures imposed on grain oriented flat-rolled electrical steel (DS414). The issue could not be resolved through consultations and a panel was composed to consider the dispute in May 2011. In addition to these anti-dumping disputes which have already reached the stage of full panel hearings, China is embroiled in two other antidumping disputes which are still at the consultation stage. DS407 was brought by the EU in May 2010 over the issue of anti-dumping measures imposed on iron and steel fasteners, essentially a tit-for-tat complaint responding to DS397 brought against the EU by China in July 2009 concerning dumping of exactly the same products. ${ }^{40}$ The final anti-dumping dispute which is still ongoing (DS422) involves anti-dumping measures imposed by the US on imports of warm water shrimp from China and consultations are still ongoing on this issue.

Apart from disputes involving anti-dumping measures imposed on key exports which China appears determined to pursue to a full panel stage, China has also been involved in disputes in which China seems unwilling to back down. The first of these dealt with the exportation of raw materials filed in June 2009 by the US and the EU. ${ }^{41}$ Mexico later joined the dispute in August 2009. ${ }^{42}$ The raw materials in question, such as coke, bauxite, fluorspar, magnesium, silicon metal, and zinc are key elements for the global chemical, steel and aluminium sectors and the complainants alleged that China was restricting their export in order to benefit domestic enterprises. Nevertheless, China responded that the restrictions in place were necessary for environmental conservation ${ }^{43}$ and refused to concede during

\footnotetext{
${ }^{39}$ Li Chen, "The NME Rule of US Antidumping Law Implicating to China," US-China Law Review 2, no. 12 (2005).

${ }^{40}$ Agence France-Presse, "China slaps final anti-dumping duties on EU steel fasteners," (Sino Daily Report, 28 June 2010) http://www.sinodaily.com/afp/100628121032.m205e2nd.html. Accessed 2 November 2010.

${ }^{41}$ Dispute DS394 with the US as complainant and DS395 with the EU as complainant.

42 Dispute DS398.

${ }^{43}$ Zhi L, "China Says 'Disappointed' at Latest WTO Move on Raw Material Export Dispute," (Gov.cn article 22 December 2009) http://www.gov.cn/misc/2009-12/22/content_1493351.htm. Accessed 14 January 2010.
} 
negotiations; thus, a single panel was composed to consider the dispute in March 2010 with panel hearings still ongoing.

2009 also brought the initiation of two more disputes against the US: DS392 regarding measures affecting imports of poultry from China and DS399 regarding imports of certain passenger vehicle and light truck tyres from China. The first dispute, initiated in April 2009, concerns a US ban on poultry imports from China, contrary to a 2004 commitment from the US to allow trade in poultry products to resume following the bird flu outbreak. $^{44}$ The second dispute, launched in September 2009, dealt with increased tariffs on tyres imported from China, which China argues are not justified as a safeguard mechanism because the US has failed to prove the necessary 'market disruption' as required in Article 16 of China's Protocol of Accession. In both disputes, consultations were inconclusive and both disputes were resolved by panel reports. Finally, China is also the respondent in a dispute (DS413) brought by the US regarding the alleged monopoly that China holds over its electronic payment services in contravention of WTO commitments under the GATS (General Agreement on Trade in Services).

Overall, China is emerging as a tenacious opponent in the WTO dispute settlement system, particularly in the anti-dumping arena or in disputes where key exports are at stake, such as footwear or poultry. China is no longer willing to meekly concede when challenged by a powerful trade partner such as the US or EU and could be thus be said to have matured as a WTO Member. On the whole, it seems clear that China's pattern of interaction with the WTO DSB has shifted from extensive third-party involvement, to reluctant participation as a respondent, to enthusiastic use as a complainant in the years since accession. The next section will consider possible reasons for this shift in dispute settlement participation.

\footnotetext{
${ }^{44}$ People's Daily Online, "China to Sue US Poultry Ban at WTO,” (11 March 2009) http://english.people.com.cn/90001/90776/90884/6611625.html. Accessed 24 January 2010.
} 


\section{Explaining China's Pattern of Interaction with the WTO DSB}

There are various explanations why China has shifted from a reluctant respondent to a more enthusiastic litigator within the WTO dispute settlement system. The first of these is that there is thought to be a cultural preference amongst East Asian Members for dispute resolution through negotiation. This reluctance has been stated as merely reflecting the "East Asian cultural aversion to open conflicts and legal settlements" as they "still cling to their non-litigious tradition of the past." ${ }^{45}$ Some commentators have even gone further, claiming that China may even view the launching of a formal complaint against it as a failure of preferred techniques of bilateral consultation. ${ }^{46}$ Indeed, it is notable that none of China's WTO disputes to date have involved another East Asian WTO Member. Rather, intraregional trade disputes have been resolved via negotiated deals, such as the Shiitake mushrooms dispute between China and Japan of 2000-1 and the laver import quota dispute between Japan, China and Korea in 2004-6. ${ }^{47}$

The concept of 'aggressive legalism' may be relevant here: that is the strategy of utilizing international legal rules as both 'sword' and 'shield' at the same time in trade disputes between sovereign nations, which was first coined in 2001 to describe a similar shift in Japan's attitude to WTO trade dispute resolution. ${ }^{48}$ However, it would perhaps be premature to label China's litigation strategy as aggressive legalism; at best, it could currently be described as "assertive legalism" 49 as China begins to bring more complaints to the WTO DSM (dispute settlement mechanism) to be resolved. Another concept which may also be useful in explaining China's DSB participation shift is that of selective adaptation. Selective adaptation describes a process by which international norms and practices are accepted and assimilated into local conditions ${ }^{50}$ and is increasingly relevant as the globalization of international laws and legal institutions continues apace. Indeed, it has been noted that "the WTO’s Dispute Resolution Understanding, particularly its provisions for binding decisions

\footnotetext{
${ }^{45}$ Kim, "East Asia in the WTO Dispute Settlement Mechanism," 262- 64.

${ }^{46}$ Qi Zhang, Consultation within WTO Dispute Settlement: A Chinese Perspective (Bern, Switzerland: Peter Lang, 2007), 288.

${ }^{47}$ Junji Nakagawa, "No More Negotiated Deals?: Settlement of Trade and Investment Disputes in East Asia," Journal of International Economic Law 10, no. 4 (2007): 859.

${ }^{48}$ Saadia M. Pekkanen, "Aggressive Legalism: The Rules of the WTO and Japan's Emerging Trade Strategy," World Economy 24, no. 5 (2002).

${ }^{49}$ Pasha L. Hsieh, "China-United States Trade Negotiations and Disputes: The WTO and Beyond," Asian Journal of WTO and International Health Law and Policy 4, no. 2 (2009): 391.

${ }^{50}$ Pitman B. Potter, The Chinese Legal System: Globalization and Local Legal Culture (London: Routledge, 2001), 2.
} 
by dispute resolution panels, reflects liberal norms of legal institutionalism." ${ }^{21}$ As these liberal norms may be dissimilar to domestic Chinese norms, it is obvious that a period of adjustment may be necessary.

Selective adaptation would also imply that institutional capacity within China would be crucial for the local implementation of international norms ${ }^{52}$ and indeed, many commentators have noted China's lack of capacity in the dispute resolution mechanism as one of the main hurdles to full participation. ${ }^{53}$ This lack of expertise in WTO law has been addressed by China's enthusiastic participation in WTO disputes as a third party, particularly in the first few years post-accession. This participation was seen as a valuable means of "learning WTO litigation and enhancing its legal expertise (including training its trade officials and Chinese international trade lawyers), rather than as a means of addressing its trade concerns." 54 A further step that China has taken in closing the resource gap is to develop better relations with the private sector, for example, enhancing the role of trade associations in identifying foreign trade barriers which may be inconsistent with WTO law, ${ }^{55}$ which can be an important tool in initiating disputes in other WTO Members.

However, although this mooted cultural preference for harmony and resolution of disputes through negotiation rather than litigation, as well as a lack of institutional capacity, may partially explain China's reluctance to initiate formal disputes with trading partners, it clearly cannot also explain the reluctance of China's key trading partners to bring trade disputes to the WTO. A benevolent view is that WTO Members wanted to give China a grace period within which to reform without the pressure of WTO dispute procedures. The hiatus between China's accession and first formal dispute taken to a full panel report in 2006 could be said to be a 'honeymoon period' for China in the WTO. In effect, this could be due to "trading partners... willing to give China some leeway in light of its recent accession",56 and also in recognition of the huge changes that were required in order to bring China in compliance with its WTO obligations. In China's Protocol of Accession and associated documents, several commitments featured a phase-in period of several years; for example, some non-tariff mechanisms such as import quotas were to be eliminated immediately upon

\footnotetext{
${ }^{51}$ Ibid., 5.

${ }^{52}$ Ljiljana Biukovic, "Selective Adaptation of WTO Transparency Norms and Local Practices in China and Japan," Journal of International Economic Law 11, no. 4 (2008): 805.

${ }^{53}$ See e.g. Kim, "East Asia in the WTO Dispute Settlement Mechanism," 264.

${ }^{54}$ Nakagawa, "No More Negotiated Deals?: Settlement of Trade and Investment Disputes in East Asia," 852.

${ }^{55}$ Yan Luo, "Engaging the Private Sector: EU-China Trade Disputes under the Shadow of WTO Law?," European Law Journal 13, no. 6 (2007): 806.

${ }^{56}$ Qin, "Trade, Investment and Beyond: The Impact of WTO Accession on China's Legal System," 740.
} 
accession, whilst for some products, such as automobiles, the phase-in period lasted until 2005. Thus, it is perhaps the case that China's trading partners did not initiate a formal dispute against China whilst the main five year transition period was continuing, but once this was completed, China was viewed as a 'mature' WTO Member and thus liable to be taken to the DSM if not seen to be playing by the WTO's rules. This was explicitly stated in a Topto-Bottom review of US-China trade policy carried out in February 2006 by the United States Trade Representative (USTR). ${ }^{57}$

Alternatively, it is also true that many Members felt that the possible risks from a dispute with China may have outweighed the eventual benefits from winning the case: "Many potential petitioners have realised they have such extensive business dealings in China in other areas that they cannot risk antagonising an important business partner. The potential threat to other areas of business if the Chinese retaliate in some way is too great a risk to take." 58 This fear of retaliation may also extend beyond the level of the individual WTO Members down to the individual businesses operating in China who do not wish to complain to their governments for fear of retaliation from Chinese officials. ${ }^{59}$

Furthermore, it has also been suggested that political factors play an undeniable role in the initiation and timing of WTO disputes. Thus, disputes brought against China, particularly by the US, cannot be divorced from broader political considerations such as pressure from Congress. For instance, the historic change in control of Congress from the Republicans to the Democrats after the 2007 mid-term elections led directly to a stronger offensive against China and the initiation of several new WTO disputes with China as respondent, as well as several pieces of new proposed legislation which could have serious consequences for trade with China. ${ }^{60}$ This hardened stance against China is "primarily driven by domestic groups and Congress, which deem America's large trade deficit with China to be the result of Chinese "unfair trade practices'."61 However, clearly not all areas of potential dispute are subject to WTO jurisdiction; for example, the valuation of the Chinese yuan is

\footnotetext{
${ }^{57}$ United States Trade Representative, "U.S.-China Trade Relations: Entering a New Phase of Greater Accountability and Enforcement- Top-to-Bottom Review" (February 2006)

http://www.ustr.gov/sites/default/files/Top-to-Bottom\%20Review\%20FINAL.pdf. Accessed 14 December 2009, 10-12.

${ }^{58}$ James P. Durling, "Beyond Doha: Reflections on the Future of Trade Remedies," in The WTO in the Twenty-

First Century: Dispute Settlement, Negotiations, and Regionalism in Asia, ed. Yasuhei Taniguchi, Alan

Yanovich, and Jan Bohanes (Cambridge Cambridge University Press, 2007), 349.

${ }^{59}$ Ostry, "WTO Membership for China: To Be and Not to Be: Is That the Answer?," 37.

${ }^{60}$ Stuart S. Malawer, "United States- China Trade Litigation in the WTO," Virginia Lawyer 56 (2007).

${ }^{61}$ Hsieh, "China-United States Trade Negotiations and Disputes: The WTO and Beyond," 376.
} 
one area which continues to cause conflict with trade partners yet is not defined as a trade barrier by the WTO.

The impact of the global financial crisis of the past few years also cannot be ignored as a potential cause of the recent upsurge in dispute settlement activity involving China. It is clear that "China's role on the global stage has grown to be even more significant amid the recent financial crisis," 62 with some countries using the 'credit crunch' as an excuse to increase protectionism at the expense of China. In fact, China has been the targeted the most frequently by 'crisis-era protectionism'; “In the past 12 months China's commercial interests have been hit 146 times by protectionist measures," ${ }^{63}$ but China has also responded by introducing protective state measures of its own. This could be partly responsible for the recent increase in disputes taken to the WTO DSB, particularly in relation to the antidumping disputes.

Therefore, there are a variety of factors which taken together can help to explain China's pattern of interaction with the WTO dispute settlement system since accession in late 2001. There may be some merit in the argument that China, along with other East Asian nations, simply prefers to resolve disputes through negotiation rather than litigation and this argument is supported by the lack of formal disputes between Asian WTO Members in general. However, it is more likely that China's initial reluctance to formally bring disputes to the WTO arose from a lack of experience in WTO litigation and the necessary institutional capacity rather than an innate cultural preference. This lack of experience was largely addressed through extensive third party participation in the first few years following accession.

Once China had gained the necessary experience, it began to participate more actively both as a respondent but also as a complainant. This coincided with increased activity from China's trading partners such as the US, responding to domestic pressure and the end of China's five-year WTO transition period, to initiate more formal complaints. The recent upsurge in complaints brought to the WTO could reflect the recent global financial crisis and consequent increase in trade barriers as countries retreat to protectionism. In particular, China has been the target of a huge number of anti-dumping investigations and as a result, has brought three complaints to the WTO in the past two years involving determinations of

\footnotetext{
${ }^{62}$ Ibid., 371.

${ }^{63}$ Simon J. Evenett, "The Unrelenting Pressure of Protectionism: The 3rd GTA Report- a Focus on the AsiaPacific Region," (London: Centre for Economic Policy Research, 2009), 21.
} 
anti-dumping. This focus on anti-dumping in China's disputes could also be because it "is a horizontal issue that affects multiple industries over a long period of time."64 This could also explain why China is more willing to settle some disputes (such as the dispute over the provision of financial information news) than others which involve trade policies of vital strategic importance.

${ }^{64}$ Luo, "Engaging the Private Sector: EU-China Trade Disputes under the Shadow of WTO Law?," 815. 


\section{Lessons to be Learnt from China's Interactions with the WTO DSM}

China's observed pattern of interaction with the WTO dispute settlement system may also have important implications both for the WTO itself and for key trading partners. It is clear that "a dispute settlement system to which a large majority of WTO Members do not have any realistic access cannot claim to be an effective system," participation in the DSM would be disquieting to say the least. In general, it is extremely worrisome that developing countries feel that resource and monetary constraints preclude their full use of the dispute settlement system, ${ }^{66}$ and this may be symptomatic of a wider imbalance in the WTO as a whole between industrialised Western nations and poorer developing countries. Specifically, the dispute settlement system "does not give weaker countries the same protection that well developed legal systems usually afford their weaker citizens." ${ }^{, 67}$

In 2003, China itself proposed placing limits on cases brought against developing country Members of the WTO, including limiting the number of cases to two which may be brought by a developed country Member against a developing country Member in any calendar year; forcing the developed country Member to pay the costs of the developing country Member if they bring a case against a developing country Member and lose; and shortening the time frame for dealing with anti-dumping disputes. ${ }^{68}$ This shows the defensive attitude of China at the time, clearly viewing the initiation of any formal WTO dispute as a letdown and may signal the need for greater assistance, both monetary and expertise, for developing country Members when dealing with the WTO DSM.

A further lesson may be the use of third party participation in disputes as a tool to learn about WTO litigation more generally. Vietnam joined the WTO in January 2007 and was quick to join two disputes as a third party, before swiftly launching its first complaint against the US in February 2010. As the complaint against the US regarding anti-dumping measures on shrimp from Vietnam is very similar to Thailand's successful case against the US which Vietnam had joined as a third party, it is clear that Vietnam may well have gained the confidence to launch their own dispute by participating in the previous dispute as a third

\footnotetext{
${ }^{65}$ Donald McRae, "Measuring the Effectiveness of the WTO Dispute Settlement System," Asian Journal of WTO and International Health Law and Policy 3, no. 1 (2008): 16.

${ }^{66}$ Parlin, "Operation of Consultations, Deterrence, and Mediation," 572.

${ }^{67}$ Zhang, Consultation within WTO Dispute Settlement: A Chinese Perspective, 286.

${ }^{68}$ World Trade Organisation (2003) Responses to Questions on the Specific Input of China: Communication from China. Document TN/DS/W/57.
} 
party. China clearly adopted this strategy of using third party participation as a learning tool in order to build legal capacity in the years immediately following accession and it may be useful for other new Members, such as Ukraine and Tonga who have yet to join a dispute even as a third party, to adopt a similar strategy.

Perhaps the most important lesson to be drawn from China's more recent involvement in WTO disputes is the obvious contrast between issues where China has conceded relatively quickly during the consultation period and issues where China is more willing to take the dispute to full panel proceedings. Generally, the latter disputes concern anti-dumping determinations and other measures which may impact upon what China regards to be key industries or exports. Therefore, trading partners initiating a complaint against China in one of these key areas should be prepared for the long-haul as China is unlikely to concede during consultations.

Overall, China's recent increased utilisation of the WTO dispute settlement forum is to be welcomed; it shows that the DSM is fulfilling its role of diverting bilateral disputes which could previously have spilled over into outright trade war. However, it's apparent that the recent economic downturn and associated rise in protectionist trade barriers may lead to even more China-related cases being brought to the WTO DSB and it will be interesting to how China reacts especially if panel reports are not favourable to Chinese arguments. It may pose a strong test of China's commitment to international legal institutions and their rules.

\section{Conclusion}

China's interactions with the WTO dispute settlement body have clearly undergone a seismic shift from accession in 2001. The first few years saw extensive third party participation, from which China gained expertise in WTO litigation, but few formal disputes. This changed in 2007 after China's five-year transition period ended and China began to be seen as a mature Member; this also coincided with domestic US political changes which led to greater pressure to pursue trade disputes with China more aggressively. Recently, China has initiated several disputes against both the EU and the US, showing a more assertive attitude to the dispute settlement system. The wider use of the WTO DSM is to be applauded as China and key trading partners are using the neutral legal mechanism provided by the WTO to resolve disputes which could otherwise escalate and cause real resentment. This shows that China's policy of 'peaceful rise' appears to be beneficial in the field of 
international trade disputes and it will be interesting to see if this continues in the future as further credit crunch-linked trade barriers continue to target China. 